\title{
New Classopollis Species From Triassic-Jurassic Boundary In Northern Iraq
}

\author{
Yasser H. Kddo \\ Department of Oil Reservoir \\ College of Petroleum and Mining \\ University of Mosul
}

(Received 18/12/2017 ，Accepted 8/10/2018)

\begin{abstract}
A new Classopollis species are described from Upper Triassic- Lower Jurassic Butmah Formation in borehole Tel-Hajar-1- northern Iraq. These are Classopollis scabratus, Classopollis polygonus, Classopollis microgranulatus, Classopollis zonatus and Classopollis crescentus; these taxa reveal distinctive morphologic features which lead to regard them as a new species.
\end{abstract}

Keywords: Classopollis, Triassic-Jurassic, Butmah Formation, Northern Iraq.

أنواع جديدة من حبوب اللقاح الحزامية من الحد الفاصل بين التراياسي ـ الجوراسي شمالي العراق

$$
\begin{aligned}
& \text { ياسر حسن قدو الكبيسي } \\
& \text { قسم هندسة الدكامن النفطية } \\
& \text { كلية هندسة النفط والتعدين } \\
& \text { جامعة الموصل } \\
& \text { الملخص } \\
& \text { انواع جديدة من حبوب اللقاح الحزامية وصفت من الحد الفاصل بين الترياسي ـ الجوارسي من } \\
& \text { تكوين بطمة في بئر تل حجر - } 1 \text { شمالي العراق. } \\
& \text { وهذه الانواع هي: }
\end{aligned}
$$

Classopollis scabratus,Classopollis polygonus, Classopollis microgranulatus,

Classopollis zonatus and Classopollis crescentus.

$$
\text { حيث أظهرت صفات مورفولوجية مميزة قادتا لاعتبارها أنواع جديدة. }
$$

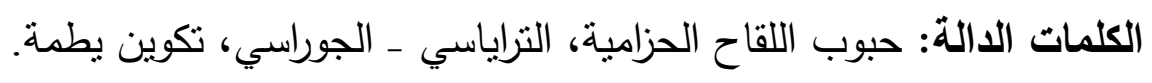




\section{INTRODUCTION}

The genus Classopollis is one of the important late Mesozoic fossil pollen grains and it has great importance in age determination and paleoecological interpretations of Mesozoic sediments. During the course of detailed palynological studies of Triassic and Jurassic strata of Butmah Formation in borehole Tel-Hajar-

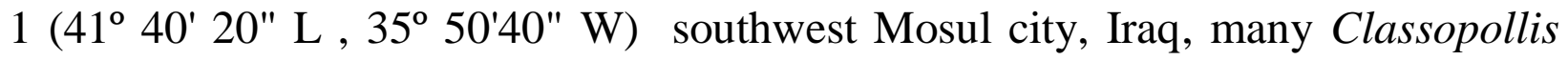
species are recorded, these are:

Classopollis itunensis, Classopollis meyerianus, Classopollis minor, Classopollis monostriatus,Classopollis murphy, Classopollis simplex, Classopollis triangulus, Classopollis torosus in additio to other new species of this study: (Classopollis scabratus, Classopollis polygonus, Classopollis microgranulatus, Classopollis zonatus and Classopollis crescentus) which showed very distinctive morphologic features. I expect that these new species will have a biostratigraphical and Paleoecological impliations. The purpose of this paper is to document these species systematically and to relate their occurrence to the palynostratigraphic sequences.

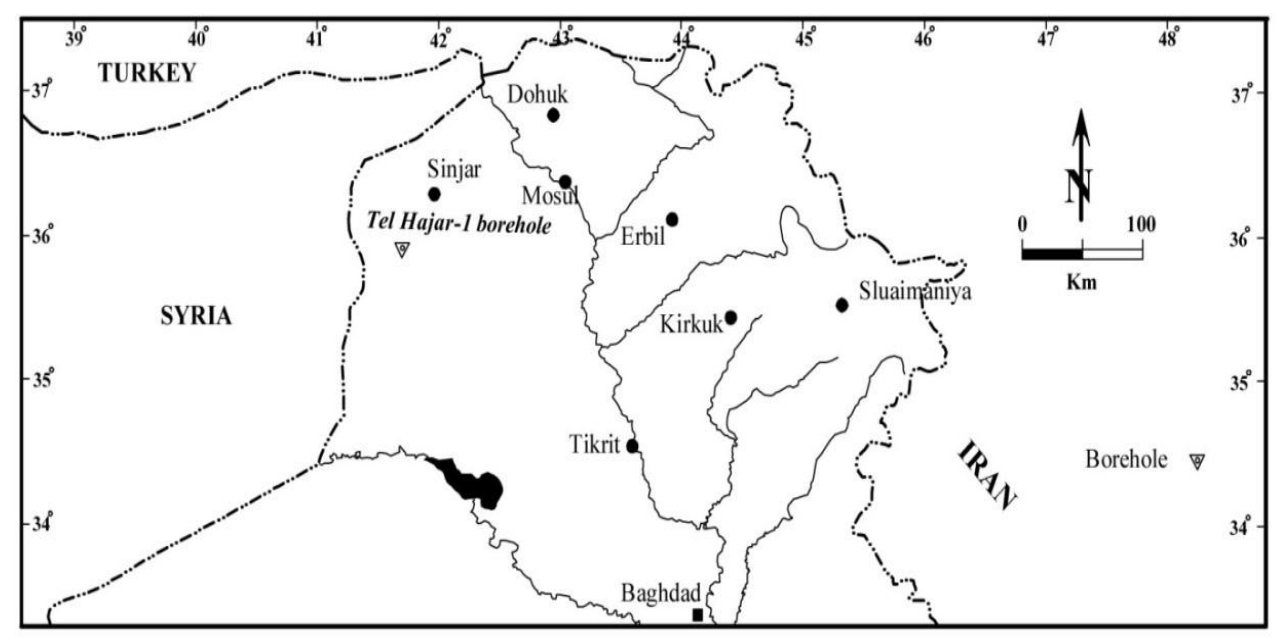

(Fig.1): Location map of borehole Tel Hajar-1

\section{STRATIGRAPHY (Material and Methods)}

This study is based on pollen grains extracted from samples representing part of Butmah Formation penetrated in borehole Tel-Hajar -1 from ( 4048-3506 m.) levels. Dunnington (1953; in Bellen et al., 1959) first described the Butmah Formation from borehole Butmah-2 southwest Mosul city (Since Butmah Formation has not described from surface exposures). The rocks penetrated in this interval are described as heterogeneous aggregate of sediment of calcareous - argillaceous and evaporitic rock suites (Fig. 2). According to (Jassim and Goff, 2006) the upper part (200m.) of the Butmah Formation in the type section consists of oolitic and detrital limestone with beds of argillaceous limestone, shale and anhydrites. The middle part $(180 \mathrm{~m}$.) is oolitic, argillaceous 
and dolomitic with sandstone and shale bed. The lower part $(120 \mathrm{~m}$.) is composed of limestone with bedded anhydrite. The lithofacies and faunal assemblages indicate that Butmah Formation was deposited in shallow water lagoonal and sabkha environments. Most samples were productive of palynomorphs. The undoubted indigenous palynoflora of the rock indicates Late Triassic ((Rhaetian)-Early Jurassic((Hettangian-Sinemurian) age for the Butmah Formation.

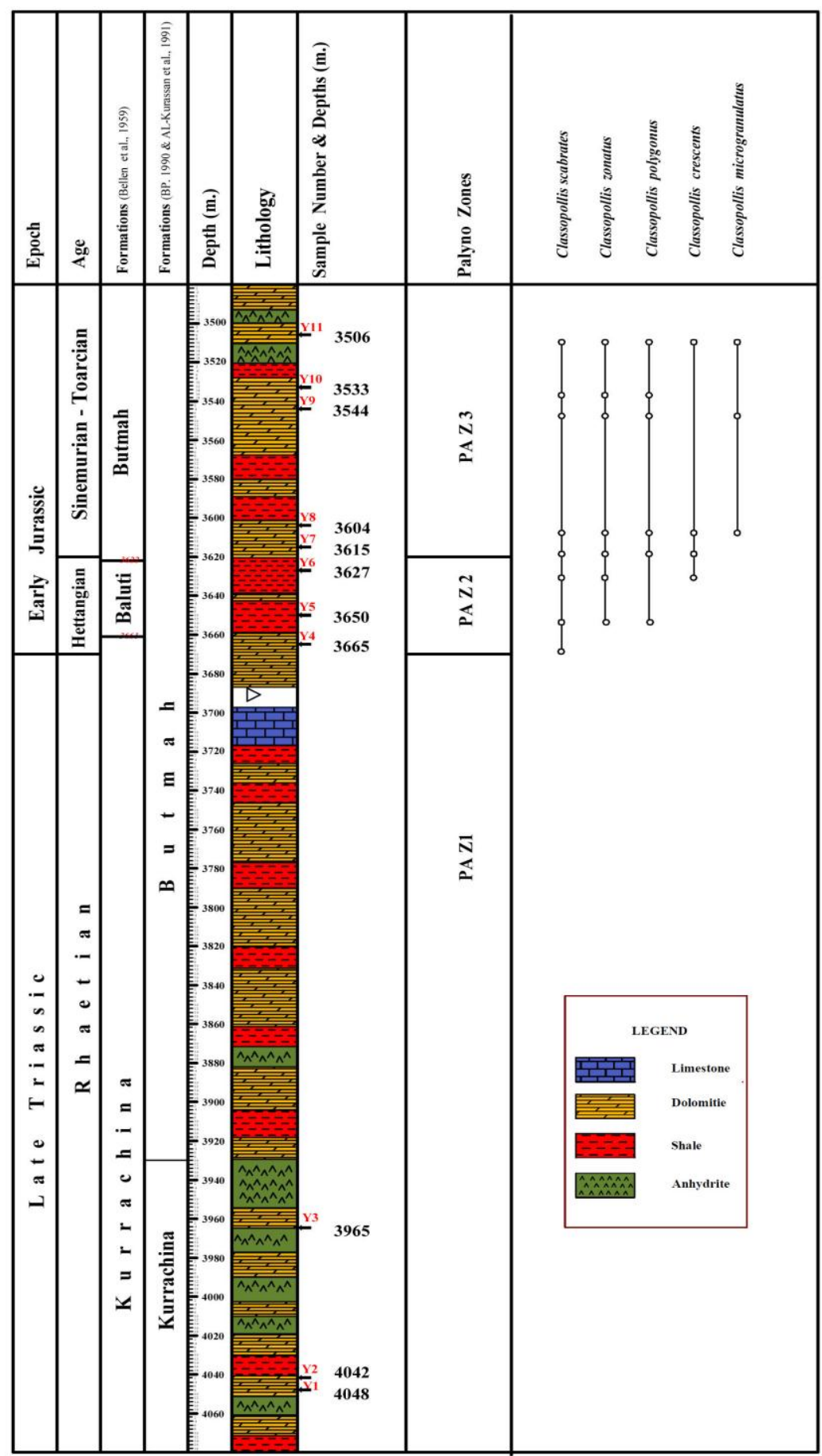

Fig. 2: Stratigraphic Succession of Borehole Tel-Hajar-1- Showing the Distribution of Species. 


\section{Circumpolles pollen}

\section{The pollen genus Classopollis Pflug, 1953}

Pollen grains are referable to the genus Classopollis Pflug are found in strata ranging in age from Permian to Eocene.

The Classopollis producing coniferous plants (Cheirolepidiaceae) were particularly abundant and widespread during the Jurassic and Cretaceous at low to mid palaeolatitudes. They extended over a broad range of habitats and flourished under warm to hot subtropical to tropical climates, (particularly under dry, especially semiarid to arid, conditions) and the abundance of the pollen produced by them is considered to be a reliable climatic and biostratigraphic marker.

Representatives of the genus Classopollis commonly dominate plant-microfossils assemblages of the Rhetian and Liassic.

Remarks: The use of the generic names Circulina Malyavkina, 1949, Corollina Malyavkina, 1949 and Classopollis Pflug, 1953 in the literature has led to a great confusion amongst palynologists. Klaus (1960) and Cornet andTraverse (1975) regarded Classopollis as a junior synonym of Corollina.Traverse (2004) proposed conservation of the name Classopollis against Circulina and Corollina because the original description of Classopollis

Pflug, 1953 was provided with good illustrations. In the present study all forms will be treated under the generic name Classopollis.

\section{Genus Classopollis Plfug, 1953}

Type species: Classopollis classoides Pflug 1953

Synonymy: Circulina Malyavkina (in part), 1949.

Circulina Mel. emend. Klaus, 1960.

Classopollis Plfug, 1953 emend. Couper, 1958.

Classopollis Pflug emend. Pocock and Jansonius, 1962.

Classopollis Pflug emend. Reyre, 1969.

Corollina Malyavkina, 1949.

Corollina Mal. emend. Klaus, 1960.

Monilapollis Chang, 1963.

Pagiophyllumpollenites Chang, 1963.

Genus: Classopollis Pflug 1953 emend. Pocock and Jansonius, 1961

Type species: Classopollis classoides Pflug, p. 91, pl. 16, figs. 29-31.

Classopollis classoides Pflug, 1953

THE TYPE SPECIES OF CLASSOPOLLIS Pflug (1953)

Proposed the species Classopollis classoides as the type species for his genus Classopollis. The genotype is illustrated in plate 16, figures 29-31, of his 1953 
paper, and it is from these figures only, together with the generic diagnosis and specific description, that the validity of the type species must be judged.

\section{GENERIC DIAGNOSIS Pflug's (1953)}

Generic diagnosis of Classopollis was "tricolporate, rarely tetracolporate. Rimula well developed, germinales gaping. Poles never quite identical in appearance." In the text (pp. 73-74), he illustrated the position of what he termed the "rimula", or main colpus. The exine structure of many specimens also appears to support the theory that Classopollis possesses characters in common with both gymnosperms and angiosperms. Our figure 5 on plate 1 illustrates a grain from the Neocomian of Alberta, which belongs to the genus Classopollis and has the appearance of a tricolpate grain with a two-layered tectate exine. Oblique squashing caused this misleading appearance.

Genus Classopollis Pflug, 1953, emended, Pocock and Jansonius

\section{Diagnosis:}

Pollen grains, distally monoporate, ovoid, spherical, or flatly acorn-shaped, exine two-layered, exoexine absent or much reduced over a circular area surrounding the distal pole and absent or reduced over a triangular area with its center at the proximal pole, intexine frequently bearing a reduced trilete scar, which has no germinal function, at the proximal pole; exine always ornamented by striations in a band or girdle surrounding the equator and interrupted (if at all) at only one point; the band usually, but not always, marking a zone of exinal thickening.

Genus: Classopollis Plfug, 1953.

Type species: Classopollis classoides Pflug, 1953.

\section{Classopollis scabratus sp.nov.}

$$
\text { Pl.1, Figs. 1-7. }
$$

\section{Diagnosis:}

2011 Classopollis sp.1. Kddo, P.71, Pl.30, Figs.14 - 20.

Pollen grains, Spherical to ovoid shape. Distal Pseudopore present, subequatorial Meandering furrow present. A trilete scar (4-8) $\mu \mathrm{m}$ long sometimes it has become no visible due to dissimilarity of wall thickness. This dissimilarity gives the wall motted appearance. Distal Pore (2-4) $\mu \mathrm{m}$ in diameter. Wall thickness (1.5-2) $\mu \mathrm{m}$. No equatorial striations. Ornamentation scabrate.

Comparison: Our specimens compare very closely in structure to Classopollis meyerianus but differ significantly in wall ornamentation, Meandering trilete scar and thick Meandering amb.

Size: 25 (32.5) $40 \mu \mathrm{m}$ from (25) spécimens.

Holotype: Borehole/Tel Hjar-1/Sample No.(Y4)/ Depths 3506(1)/ R.111.9, 2.1. 
Derivation: The specific epithet is drived from the nature of the Wall thickening .

\section{Classopollis polygonus sp.nov.}

Pl.1, Figs. 8-15.

\section{Classopollis sp.2. Kddo, P.71, PI.31, Figs.1 - 7.}

Diagnosis: Pollen grains, spherical to ovoid shape. Subequatorial furrow thin sometimes disappear under ornamentation elements. Trilete scar weak. Distal pole indistinct. Wall thickness (1) $\mu \mathrm{m}$. Ornamentation different types of thick Muri come into being Polygonal structures, this structures different in type and size, always one of this polygons appears near equatorial sulcus giving incorrect thought as it is a Distal pole of pollen grain. No equatorial striations.

Size: $24(29) 34 \mu \mathrm{m}$ from (20) specimens.

Comparison: This species distinguishable from other Classopollis species by thick reticulate ornamentation and the Polygonal structure near equatorial sulcus.

Holotype: Borehole /Tel Hjar-1 /Sample No. (Y8)/ Depths 3604(2)/ R.121, 6.9.

Derivation: The specific epithet is derived from the nature of Polygonal strucures

\section{Classopollis microgranulatus sp.nov. Pl.2, Figs.1-4. 2011 Classopollis sp.3. Kddo, P.72, Pl.31, Figs.8-11.}

Diagnosis:Pollen grains, spherical shape, Subequatorial Sulcus obvious sometimes become indistinct. A triletes scar (5 - 9) $\mu \mathrm{m}$ at length. Distal pore (4-6) $\mu \mathrm{m}$ Wall thickness (1) $\mu \mathrm{m}$ has red brownish in color. Ornamentation: Minute grana (1) $\mu \mathrm{m}$ long, unevenly distributed with some parts of the pollen surface smooth .No equatorial striations. Size: $25(32.5) 40 \mu \mathrm{m}$ from (10) specimens.

Comparison: Our specimens compare very closely in structure to C.torosus, but differ significantly in size and distributions of the ornamentation elements on the exine and the absences of equatorial striations.

Holotype: Borehole /Tel Hjar-1 /Sample No. (Y9)/ Depths 3544(1)/ R.123.9, 7.1.

Derivation: The specific epithet is derived from shape and distribution of the minute ornementation. 


\section{Classopollis zonatus sp.nov.}

\section{Pl.2, Figs.5-7.}

\section{Classopollis sp.4. Kddo,P.72, Pl.31,Figs.12 - 14.}

Diagnosis: Pollen grains, spherical to ovoid shape, subequatorial sulcus distinct, surrounding by thick wall like inner zone. Trilete scars indistinct . Distal pore surrounding by thick inner zone .No equatorial striations. Wall thickness $(0.5) \mu \mathrm{m}$. Ornamentation: Laevigate to Microgrnulate.

Size: 27 (36) $45 \mu \mathrm{m}$ from (20) specimens.

Comparison: Our specimens compare very closely in structure to Classopollis meyerianus but differ significantly in Distal pore and subequatorial sulcus surrounding by thick inner zone.

Holotype: Borehole /Tel Hjar-1 /Sample No. (Y11)/ Depths 3506(1)/ R.108.4, 7.

Derivation: The specific epithet is derived from the nature of thickend zone .

\section{Classopollis crescentus sp.nov. \\ Pl.2, Figs.8,9. \\ 2011 Classopollis sp.5. Kddo,P.72, Pl.31,Figs.15, 16.}

Diagnosis: Pollen grain, spherical to ovoid shape, Subequatorial sulcus distinct with crescntric compression fold developed to make crescent shape parallel to the amb of pollen grain. Trilete scars weak (5) $\mu \mathrm{m}$ long. Distal pole (3) $\mu \mathrm{m}$ diameter. Ornamentation: Scattered uneven grana and short baculae (1-5) $\mu \mathrm{m}$.

No equatorial striations.

Size: $27(28.5) 30 \mu \mathrm{m}$ from (7) specimens.

Comparison: Our specimens compare very closely in structure to C.torosus but differ significantly in no equatorial striation and the appearance of compression fold (crescent shape) near subequatorial sulcus which parallel the amb of pollen grain.

Holotype: Borehole /Tel Hjar-1 /Sample No. (Y8)/ Depths 3604(2)/ R.124.3, 4.8.

Derivation: After the specific epithet is drived from the nature of the Shape of compression fold. 


\section{REFERENCES}

Bellen, R. C., Van, Dunnington, H. V., Wetzel, R. and Morton, D., 1959. Lexique Stratigraphique International Asie, Iraq. Intern. Geol. Congr. Comm. Stratigr. 3, Fasc.10a, pp.1 - 333.

Cornet, B. and Traverse, A., 1975. Palynological Contributions to the Chronology and Stratrigraphy of the Hartford Basin in Connecticut and Massachusetts. Geoscience and Man, XI: 1 - 33.

Dunnigton, H. V., 1953. Subsurface Rock Unit Nomenclature for Northern Iraq. Manuscript Report No. IDLR, INOC Library, Baghdad.

Jassim, S. and Goff, J., 2006. Geology of Iraq. Dolin, Prague and Moravian Museum, Brno, Czech Republic, 337 p.

Kddo, Y. Hassan ., 2011. Palynostratigraphy of Late Triassic-Early Jurassic Strata in Boreholes Tel-Hajar-1 and Kand-1 Northern Iraq. Unpublished Ph.D. Thesis, Mosul University, $198 \mathrm{p}$.

Klaus, W., 1960.: Sporen der Karnischen Stufe der ostalpinen Trias. Jahrbuch der Geologischen Bundesanstalt, Sonderband, 5:107-183, pl. 28 - 38.

Pocock, S.A.J. and Jansonius, J., 1961. The pollen genus Classopollis Pflug, 1953. Micropaleontology, Vol. 7, pp. 439 - 449.

Traverse, A., 2004. Proposal to Conserve the Fossil Pollenmorpho Generic Name Classopollis against Corollina and Circulina: Taxon, Vol. 53, pp. 847 - 848. 


\section{PLATE 1}

Fig.1: Classopollis scabratus / Tel Hjar-3506(1)/ R.110.9, 0.7/Size:32 $\mu$.

Fig.2: Classopollis scabratus / Tel Hjar-3544(1)/ R.122.4, 9/Size:29 $\mu$.

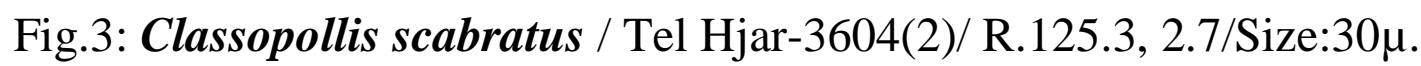

Fig.4: Classopollis scabratus / Tel Hjar-3506(1)/ R.111.9, 2.1/Size:26 $\mu$.

Fig.5: Classopollis scabratus/ Tel Hjar-3604(2)/ R.117.3, 8.7/Size:34 $\mu$.

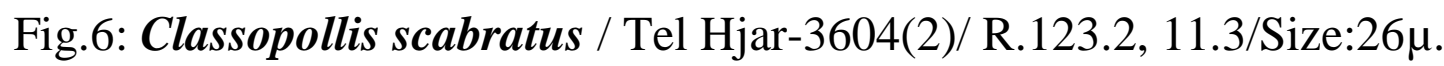

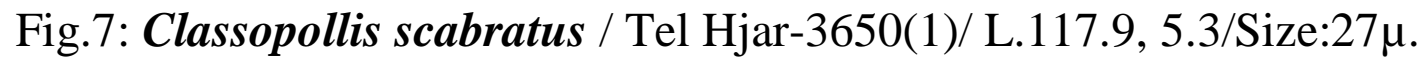

Fig.8: Classopollis polygonus / Tel Hjar-3604(2)/ R.121, 6.9/Size:31 $\mu$.

Fig.9: Classopollis polygonus / Tel Hjar-3544(1)/ R.111, 6.5/Size:30 $\mu$.

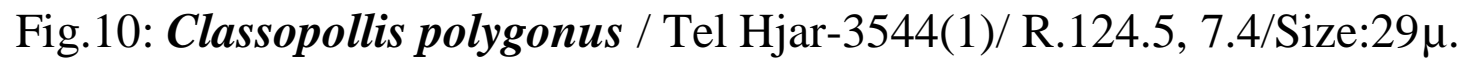

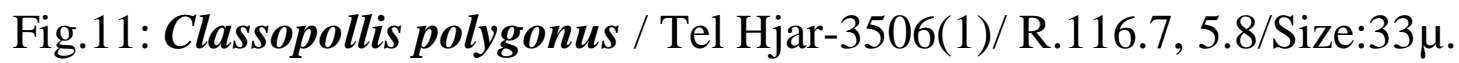

Fig.12: Classopollis polygonus / Tel Hjar-3544(1)/ R.120.9, 11.3/Size:28 $\mu$.

Fig.13: Classopollis polygonus / Tel Hjar-3506(1)/ R.117, 5.1/Size:31 $\mu$.

Fig.14: Classopollis polygonus / Tel Hjar-3544(1)/ R.127.4, 11.8/Size:36 4 .

Fig.15: Classopollis polygonus / Tel Hjar-3506(2)/ L.101, 2.1/Size:29 $\mu$. 


\section{Plate-1}
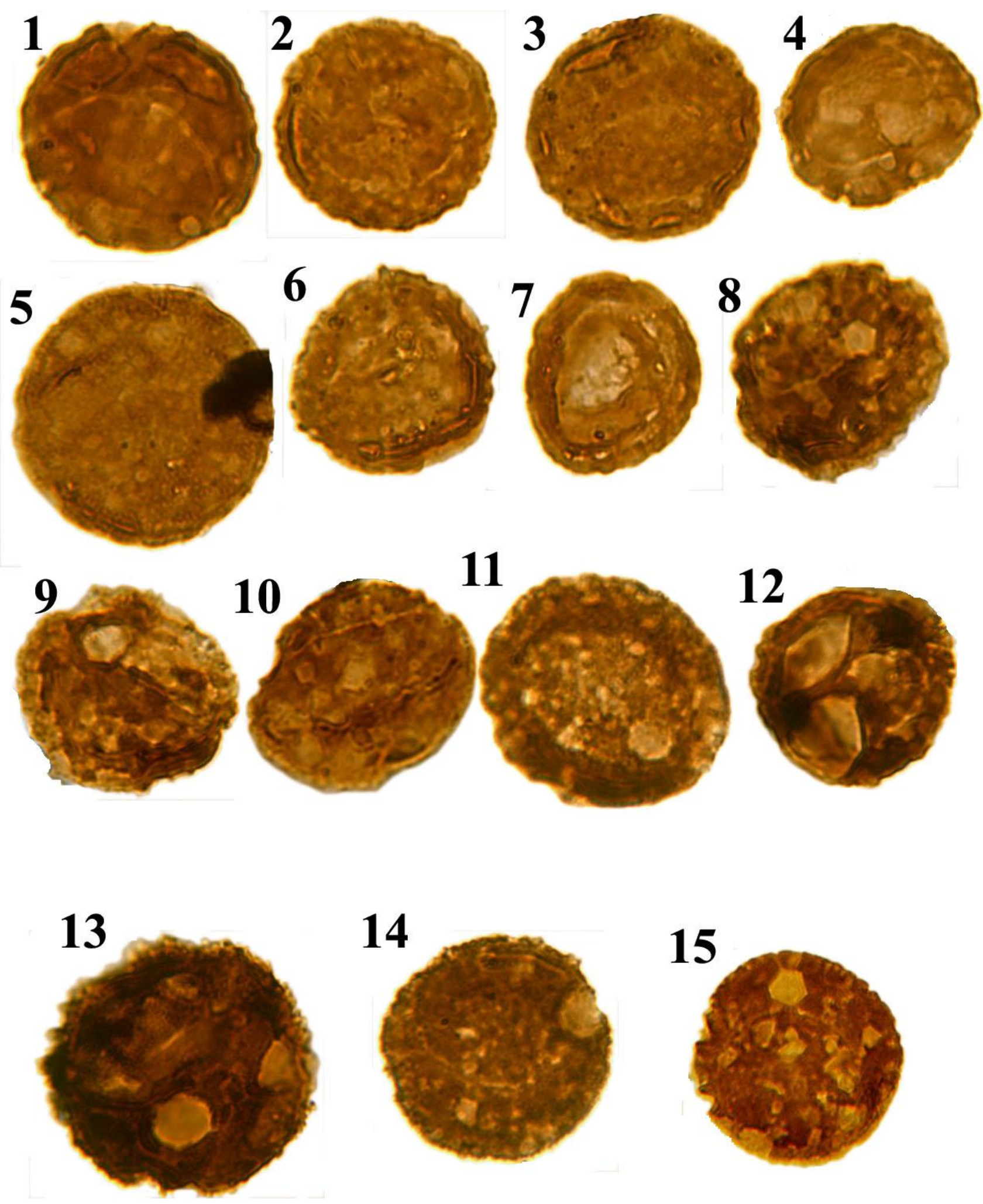


\section{PLATE 2}

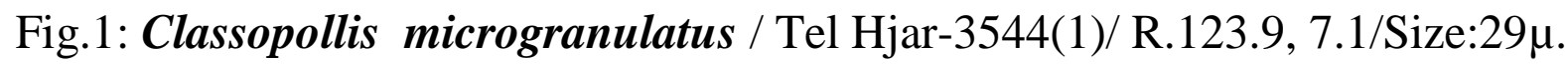

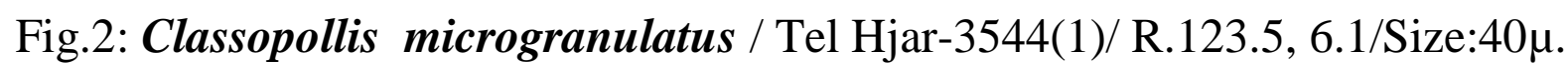

Fig.3: Classopollis microgranulatus /Tel Hjar-3506(1)/ L.134.3, 3.3/Size:30u.

Fig.4: Classopollis microgranulatus / Tel Hjar-3544(1)/ R.125.8, 9/Size:32 $\mu$.

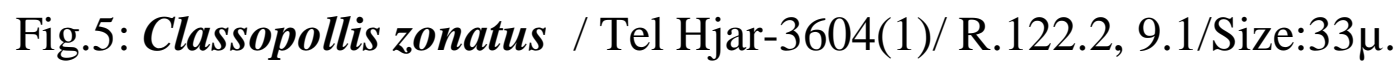

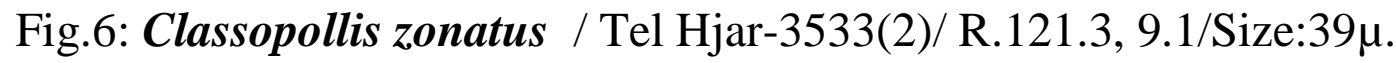

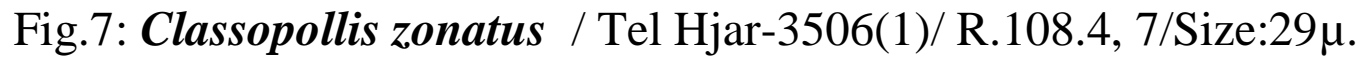

Fig.8: Classopollis crescentus / Tel Hjar-3604(2)/ R.122.2, 5.9/Size:29 $\mu$.

Fig.9: Classopollis crescentus / Tel Hjar-3604(2)/ R.124.3, 4.8/Size:29 $\mu$. 


\section{Plate-2}

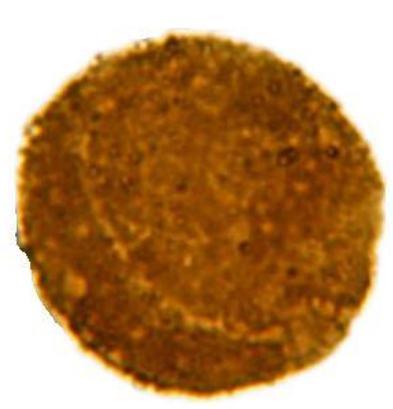

1

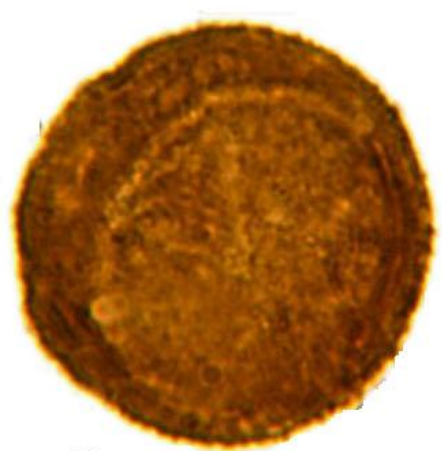

2

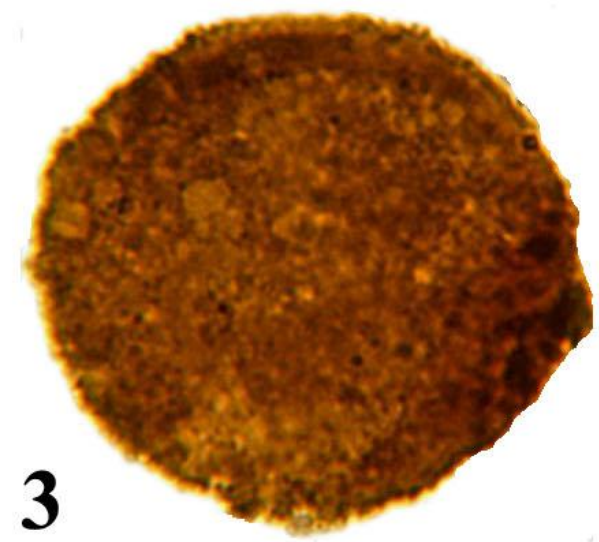

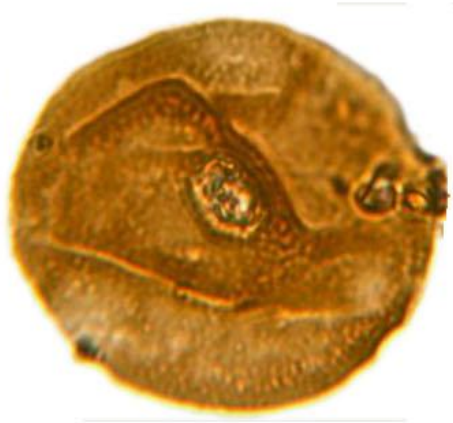

5 4

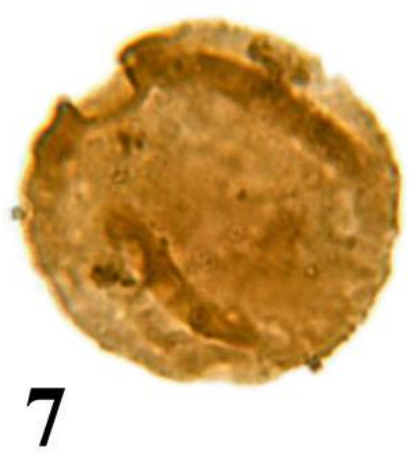

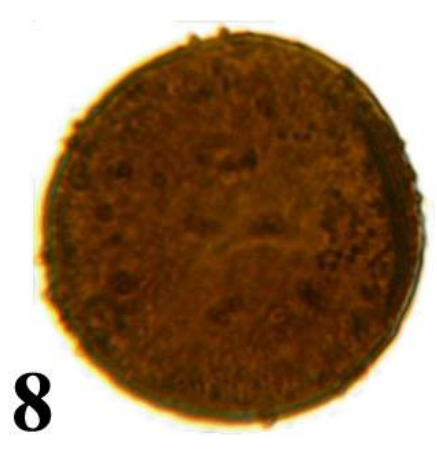

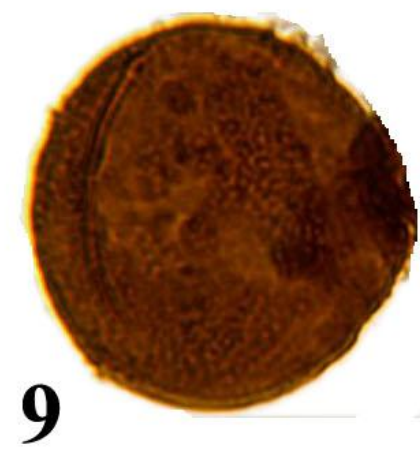

